\title{
Yeni bir izotonik içecek olarak; nar, kızılcık ve karadut suları ile zenginleştirilmiş elma suyu üretim olanakları
}

\section{As a new kind of isotonic drinks; the possibilities of the production of apple juice enriched by pomegranate, cranberry and black mulberry juice}

\author{
Öznur TOĞRUL' ${ }^{1}$, ibrahim HAYOĞLU ${ }^{*}$ (D) \\ ${ }^{1}$ Harran üniversitesi, Mühendislik Fakültesi, Gıda Mühendisliği Bölümü, Şanlıurfa
}

To cite this article:

Toğrul, Ö. \& Hayoğlu, i. (2020). Yeni bir izotonik içecek olarak; nar, kızılcık ve karadut suları ile zenginleştirilmiş elma suyu üretim olanakları. Harran Tarım ve Gıda Bilimleri Dergisi, 24(2): 165-173.

DOI: 10.29050/harranziraat.622179

Address for Correspondence: Ibrahim HAYOĞLU e-mail:

hayoglu@gmail.com

Received Date:

19.09.2019

Accepted Date:

29.01.2020

(C) Copyright 2018 by Harran University Faculty of Agriculture. Available on-line at www.dergipark.gov.tr/harranziraat
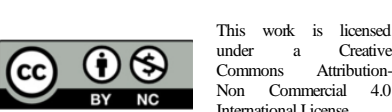

öz

Bu çalışmada ülkemizde yaygın olarak kullanılan nar, kızılıı ve karadut gibi yüksek oranda fenolik ve antioksidan madde içeren meyvelerin suları elma suyuna katılarak besin değeri arttırılmış yeni bir izotonik içecek elde edilmiş ve elde edilen ürünün bazı özellikleri incelenmiştir. Farklı formülasyonlarda hazırlanmış içecekler $500 \mathrm{~mL}$ lik cam şişelerde ve oda sıcaklığında 180 gün süreyle depolanmıştır. Yapılan istatistiksel değerlendirmeler sonucunda; depolama boyunca; asitlik düzeylerinde bir artma meydana gelirken, $\mathrm{pH}$, renk, toplam fenolik madde (TFM) ve antioksidan değerlerinde bir azalma görülmüştür. Toplam kuru madde miktarı, suda çözünür kuru madde miktarı (SÇKM) ve kül değerlerinde meydana gelen değişimler istatiksel olarak önemsiz bulunmuştur. Kül değerleri ortalama 0.385-0.422 (\%) aralığında bulunmuştur. TFM değeri en yüksek nar-elma içeceğinde 50.49-101.10 mg gallik asit/g aralığında belirlenmiştir. Yapılan analizler ve duyusal değerlendirmeler sonucunda içeceklerin oda sıcaklığında kolaylıkla depolanabileceği ve böyle bir ürünün tüketiciler tarafından talep göreceği belirlenmiştir.

Anahtar Kelimeler: İzotonik, Elma, Nar, Kızılcık, Karadut

\section{ABSTRACT}

In this study, a new isotonic drink had been prepared whose nutrition level increased by adding frequently local-consumed fruits of each pomegranate, cranberry and black mulberry juices which contains phenolic and antioxidant into apple juices. The drinks prepared at stated ratios had been stored at $500 \mathrm{~mL}$ glass bottles at room temperature in time of 180-days. In the result of evaluations by statistics, it is understood that there is an increase in acidity level and a decrease in $\mathrm{pH}$, colour, TFM and antioxidant levels during storage. Also, it is found that adding other fruit juices into apple juice resulted the product to be less liked in sensation. The changes occurring in the total amount of dry matter, TSS and ash values are found statistically in significant. Ash values are found in the average range $0.385-0.422(\%)$. The value of total phenolic compound (TFM) is determined in the range of $50.49-101.10 \mathrm{mg}$ gallic acid/g in the highest pomegranate-apple beverage. It is determined that drinks can be stored easily at room temperature for a certain period and such a product will be demanded by consumers.

Key Words: Isotonic, Apple, Pomegranate, Cranberry, Black mulberry

\section{Giriş}

Son yıllarda yapılan bilimsel çalışmalar sayesinde bilinçli tüketicilerin meyve sebze tüketiminde onların tat, aroma, lezzet veya kokularının yanında içerdikleri vitamin ve mineral değerlerini de dikkate aldıklarını göstermektedir (Yıldırım ve ark., 2016; Özgen ve Tokbaş 2007). Sebze ve meyve tüketimi kanser ve kardiyovasküler hastalıklar başta olmak üzere 
birçok hastalığa karşı koruma sağlamaktadır. Bunu sebze ve meyvelerde bulunan antioksidan özelliğe sahip fenolik bileşikler, E vitamini, karotenoidler ve askorbik asidin sağladığı düşünülmektedir (Oliveira et al., 2007).

Sporcu içecekleri; karbonhidrat, sıvı ve elektrolitlerin hızlı bir şekilde yerine konmasını sağlamak amacıyla formüle edilmiş karbonhidratelektrolit içeren ürünlerdir. Değişik oranlarda sıvı, elektrolit ve karbonhidrat içeriklerine göre hipotonik, izotonik ve hipertonik olmak üzere üç çeşit sporcu içeceğinden bahsedilebilir (Çizelge 1).

Çizelge 1. Elektrolit ve karbonhidrat içeriklerine göre sporcu içecekleri (Mackenzıe, 2000)

Table 1. Sports drinks according by contents of electrolyte and carbohydrate

\begin{tabular}{|c|c|}
\hline $\begin{array}{c}\text { Tip } \\
\text { Type }\end{array}$ & $\begin{array}{c}\text { İçerik } \\
\text { Content }\end{array}$ \\
\hline İzotonik & $\begin{array}{c}\text { Sıvı, elektrolitler ve \%6-8 oranında } \\
\text { karbonhidrat }\end{array}$ \\
\hline Hipotonik & $\begin{array}{c}\text { Elektrolitler, sıvı ve düşük oranda } \\
\text { karbonhidrat }\end{array}$ \\
\hline Hipertonik & Yüksek derecede karbonhidrat \\
\hline
\end{tabular}

İzotonik İçecekler; çabuk terleme ile kaybedilen sıvıların yerine geçer ve karbonhidrat desteği sağlar. İzotonik içecekler orta ve uzun mesafe koşucuları veya takım sporcuları gibi birçok sporcunun tercihidir. Hem uzun süren egzersiz hem de terleme sonucunda vücudun karbonhidrat depolarının tükenmesi ve dehidratasyon ortaya çıkan iki önemli faktördür. Özellikle hava sıcaklığının yüksek olduğu yaz azlarında, ister amatör olarak spor yapanlar olsun isterse profesyonel sporcular olsun bol miktarda terleme olasılığı ile karşı karşıyadırlar. Antreman öncesinde, sırasında ve sonrasında karbonhidrat tüketmek kandaki glikoz miktarının aşırı düşmesini engeller ve vücudun glikojen stoklarını korumasına yardımcı olur. Sporcuların çoğu spor öncesi veya sırasında yiyecek tüketemeyecekleri için karbonhidratlar açısından zengin formüllü içeceklerin tüketilmesi yararlı olur (Rehrer, 1994).

İzotonik içecek \%4-8 karbonhidrat çözeltisi içeren içeceklerdir. İzotonik içecekler, yüksek oranlarda sıvı alımını teşvik ederler ve vücut için gerekli olan minerallerin daha hızlı ve etkili yoldan alımını sağlarlar. Kan dolaşımının, kardiyovasküler sistemin ve vücut ısısının dengelenmesini mineral açığını giderecek şekilde takviye sağladıkları için, performansın artmasına yardımcı olurlar. Genellikle sporcular tarafından tercih edilen bu içecekleri her yaş grubu tüketilebilir. Ülkemizde izotonik içecekler toplum tarafından genellikle sporcuların içtiği bir içecek olarak bilinmektedir. Bu çalışmada yöresel olarak yaygın kullanılan nar, kızılcık ve karadut gibi yüksek oranda fenolik ve antioksidan madde içeren meyveler, elma sularına katılarak elde edilen meyve sularının besin değerlerinin arttırılarak yeni bir izotonik içecek yapııması amaçlanmıştır. Fonksiyonel özellik kazandırımış izotonik içeceklerin meyve suyu sanayisine katkıda bulunulacağı ve sadece sporcuların değil herkesin tüketebileceği bir içecek olarak tercih edilebileceği düşünülmektedir.

Elma (Malus domestica), gülgiller familyasından kültürü yapılan ağaçların yenen meyvesidir. Elma; A, B1, B2, C ve E vitaminleri; fosfor, kalsiyum, potasyum, sodyum, magnezyum gibi birçok mineral maddeleri; organik asitleri; doğal aroma maddeleri ile fenolik bileşenler, askorbik asit, pigmentler ve antioksidan maddeler gibi fitokimyasalları içermektedir (Karaman ve ark. 2010). Türkiye'de meyve suyuna işlenen meyveler içerisinde \%65-70'lik bir oranla elma ilk sırayı almaktadır. Meyve Suyu Endüstrisi Derneği (MEYED) raporunda meyve sularına işlenen meyvelerin miktarı 2010 yılında 825 bin tondur ve elma bu işlenen meyveler arasında 376 bin ton ile ilk sırada yer almaktadır (Anonymous, 2012).

Nar (Punica granatum L.) Punicacea familyasında yer alan, tropik ve subtropik iklim özelliğine sahip bölgelerde yaygın olarak yetiştirilen bir meyve türüdür (Fadavi et al., 2005). Nar suyu \%85,4 oranında su ve önemli miktarlarda suda çözünebilir kuru madde, şeker, antosiyaninler, fenolikler, askorbik asit ve protein içermektedir (Özden ve ark. 2017; Kulkarni et al., 2005).

\section{Kızılcık (Cornus mas L.), Cornaceae} familyasından yer alan 10-15 mm uzunluğunda, zeytin büyüklüğünde mor, sarı ya da kırmızı renkli, ekşi tada sahip meyvelerdir (Ercişli, 2004). Çok yıllık odunsu bir bitki olan kızılcık yüksek miktarda C vitamini içermektedir. İçerdiği antosiyanin pigmentlerinden dolayı bordo-kırmızı renge sahip 
olan meyve çok zengin askorbik asit, antosiyanin, fenolik bileşen ve antioksidan kaynağıdır (Demir, 2003).

Karadut (Morus nigra) Moraceae ailesinin bir üyesi olup, Türkiye'de fazlaca yetiştirilmektedir. Meyve temel olarak şeker, sitrik asit ve malik asit gibi organik asitler, fenolik asitler ve antosiyaninlerden oluşmaktadır (Elmacı ve Altuğ, 2002).

\section{Materyal ve Yöntem}

İzotonik içeceklerin üretimin de kullanılan elma, karadut ve nar suyu, Anadolu Etap firmasından konsantre olarak temin edilmiş olup, briks değerleri 65-70 'dır. Kızılcık suyu, Elite Naturel firmasından temin edilmiş olup, briks değeri 10'dur.

\section{İzotonik içecek örneklerinin hazırlanması}

Örnekler belirlenen oranlarda tuz ve koruyucu eklenerek Çizelge 2'deki formülasyona uygun olarak Şekil 1'de gösterildiği gibi hazırlanmıştır. İçecekler pazarlama şartları dikkate alınarak 6 ay boyunca $500 \mathrm{~mL}$ 'lik beyaz renkli cam şişelerde ve oda sıcaklığında depolanmıştır.

Çizelge 2. İzotonik içeceklerinde bulunan temel bileşenler ve oranları

Tablo 2. The basic components and their proportion found in isotonic drinks

\begin{tabular}{|c|c|c|c|}
\hline $\begin{array}{c}\text { 1.Örnek } \\
\text { Sample 1 }\end{array}$ & $\begin{array}{c}\text { 2. Örnek } \\
\text { Sample 2 }\end{array}$ & $\begin{array}{c}\text { 3. Örnek } \\
\text { Sample 3 }\end{array}$ & $\begin{array}{c}\text { 4. Örnek } \\
\text { Sample 4 }\end{array}$ \\
\hline Elma suyu (\%100) & Elma suyu (\%80) & Elma suyu (\%80) & Elma suyu (\%80) \\
\hline$\ldots .$. & Nar suyu (\%20) & Kızılcık suyu (\%20) & Karadut suyu (\%20) \\
\hline $\mathrm{NaCl} 20 \mathrm{mg} / 100 \mathrm{~mL}$ & $\mathrm{NaCl} 20 \mathrm{mg} / 100 \mathrm{~mL}$ & $\mathrm{NaCl} 20 \mathrm{mg} / 100 \mathrm{~mL}$ & $\mathrm{NaCl} 20 \mathrm{mg} / 100 \mathrm{~mL}$ \\
\hline $\mathrm{K}-$ Sorbate $1.0 \mathrm{mg} / 100 \mathrm{~mL}$ & $\mathrm{~K}-$ Sorbate $1.0 \mathrm{mg} / 100 \mathrm{~mL}$ & $\mathrm{~K}-$ Sorbate $1.0 \mathrm{mg} / 100 \mathrm{~mL}$ & $\mathrm{~K}$-Sorbate $1.0 \mathrm{mg} / 100 \mathrm{~mL}$ \\
\hline
\end{tabular}

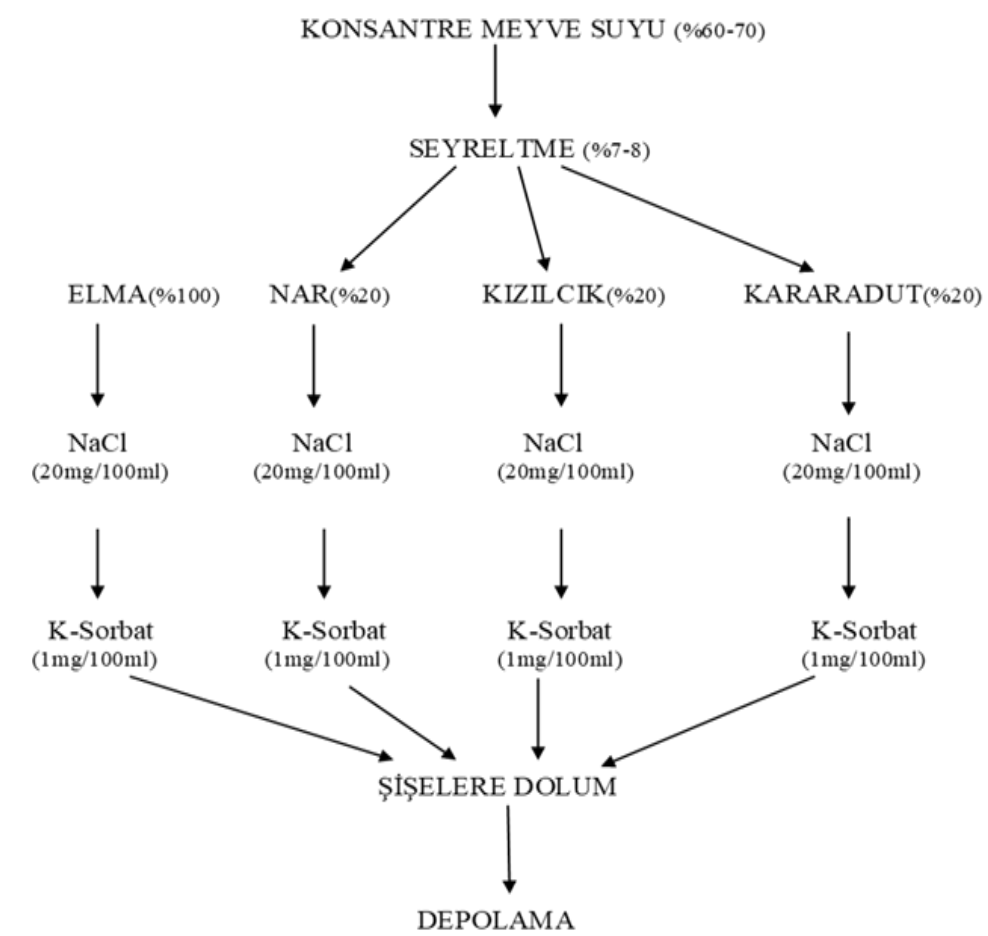

Şekil 1. Farklı oranlarda hazırlanan izotonik içeceklerin üretim akış şeması

Figure 1. The flow chart of production of isotonic drinks prepared at different proportion

Hazırlanan örneklerde depolamanın başında ve depolama süresince peryodik olarak $\mathrm{pH}$, titrasyon asitliği (Cemeroğlu, 2007), Toplam kurumadde (Ercişli ve Orhan, 2007), Suda çözünür kuru madde (Gould, 1977), Kül tayini, Renk (Cemeroğlu, 2007),
Toplam antioksidan (Zaouaya et al., 2012; Gironés-Vilaplana et al., 2012; Espín et al., 2000), Toplam fenolik (Medina-Remon et al., 2009) analizleri yapılmıştır.

İzotonik içeceklerin duyusal özellikleri on 
kişiden oluşan panelist grup tarafından Görünüş, koku, tat, renk, ağızda bıraktığı his ve gecikmiş tat (sonradan hissedilen tat) gibi özellikler dikkate alınarak değerlendirilmiştir. (Altuğ ve Elmacı, 2011).

Denemeler 2 paralelli ve 3 tekerrürlü olarak yapılmış ve değerlendirmede SPSS paket programı kullanılmıştır. $\mathrm{P}<0.01$ veya $\mathrm{P}<0.05$ anlamlı olarak değerlendirilmiştir. Gruplardaki ortalamalar arasındaki farklar Duncan testi ile belirlenmiştir. Duyusal değerlendirme verileri ANOVA $4 \times 3$ tekrarlı ölçüm kullanılarak yapılmıştır (Curran et al., 1996).

\section{Araştırma Bulguları ve Tartışma}

İçeceklerin $\mathrm{pH}$ ve titrasyon asitliği değerleri

Hazırlanan izotonik içeceklerin $\mathrm{pH}$ ve titrasyon asitliği değerleri 180 gün boyunca periyodik olarak takip edilmiştir (şekil 2).

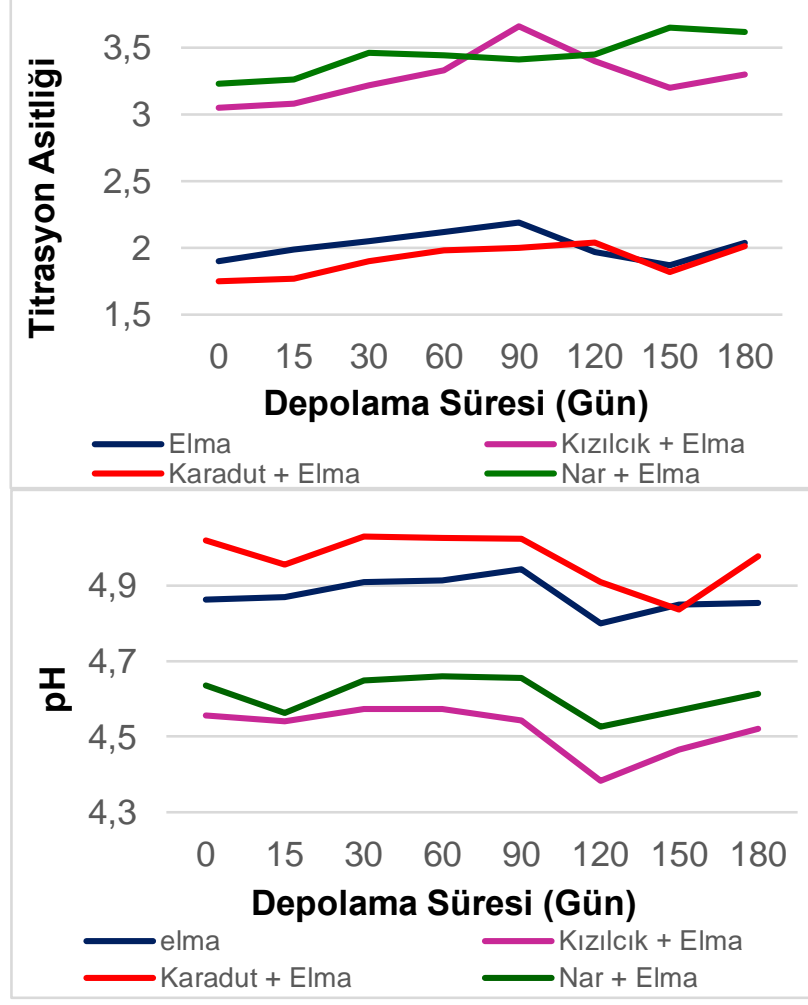

Şekil 2. Depolama süresince titrasyon asitliği ve $\mathrm{pH}$ değerlerindeki değişimler

Figure 2. Changes in $\mathrm{pH}$ and titration acidity values during storage

Grafiklerden görülebileceği gibi; farklı formülasyonlarda hazırlanan izotonik içeceklerin hepsinde $\mathrm{pH}$ değerlerinde depolama boyunca belirgin bir değişim gözlenmemiştir. Depolama periyodunun sonunda az da olsa görülen rakamsal değişim istatistiksel anlamda önemli bulunmuştur $(\mathrm{P}<0.05)$. İçeceklerin $\mathrm{pH}$ değerleri $5^{\prime}$ in altında olup depolama boyunca bu durum değişmemiştir. Grup içerisinde karadut-elma karışımının asitliği en düşük, $\mathrm{pH}$ değerlerinin ise yüksek olduğu görülmüştür. Depolama süresi boyunca ortalama asitlik değerlerindeki değişimler her ne kadar az gibi gözükse de her dört grupta da istatistiksel açıdan önemli bulunmuştur $(P<0.05)$. Depolama boyunca dört grupta da artış olduğu gözlemlenmiştir. Asitlik değerleri sırasıyla en yüksek nar-elma, kızılcık-elma, elma ve karadutelma şeklindedir.

Literatüre bakıldığında karaduta ait $\mathrm{pH}$ değerlerinin 3.30-5.65 aralığında olduğu belirtilmiştir (Akbulut ve ark., 2006; Ercişli and Orhan 2007; Hepsağ ve ark,. 2012). Bounous ve Zanini (1987) İtalya'da kızılcık meyvelerinin farklı yetiştirme alanlarında pomolojik ve kimyasal bileşimleri tespit etmek amacıyla yürüttükleri bir çalışmada kızılcık meyvesinde pH 4.82 olarak bulmuşlardır. Tüfekçi (2008), piyasadaki bazı meyve sularının gıda mevzuatına uygunluğunu incelediği bir çalışmasında; nar suyunun $\mathrm{pH}$ değerini ise 3.39-3.57 arasında, elma suyunun $\mathrm{pH}$ değerini ise 3.49-4.01 arasında bulduklarını belirtmiştir. Literatürde $\mathrm{pH}$ değerleri için bir sınırlamaya rastlanmamıştır.

Demir ve Kalyoncu (2003) yaptıkları bir araştırmada kızılcık meyvesinin toplam asitliği (malik asit cinsinden) $1.852-2.348 \mathrm{~g} / \mathrm{mL}$ olarak tespit etmişlerdir. Özgen ve ark. (2009b)'nın yaptıkları çalışmada ise olgun karadut meyvelerinde asitlik ortalama \%2'nin üzerinde belirlenirken, beyaz dutlarda asitlik miktarı \%0.530.75 arasında değişmiştir.

Örneklerin $\mathrm{pH}^{\prime}$ larında görülen hafif artışa paralel olarak toplam asitlikte de artış görülmüş olup bu durumun depolama boyunca zaman içerisinde meydana gelen reaksiyonlar sonucunda tampon özellik gösteren bazı bileşenlerin düşük düzeyde de olsa tortu oluşturarak ortamdan ayrılmasından kaynaklanabileceği düşünülmektedir. 
Toplam kuru madde ve SÇKM değerleri

İzotonik içeceklerde 6 aylık depolama süresince kuru madde ve SÇKM değerleri korunmuş olup SÇKM değeri 8, toplam kurumadde değeri 7.7-8.0 arasında değişmektedir. Bu süre boyunca meydana gelen farklılıklar istatistiksel açıdan önemsiz bulunmuştur ( $P>0.05)$.

Ersoy (2013) sporcu içeceklerinde yapmış olduğu bir çalışmada, hipotonik içeceklerin briks değerlerinin 4 ten küçük, izotonik içeceklerin briks değerlerinin 6 ile 8 arasında, hipertonik içeceklerin briks değerlerinin ise 8 den büyük olduğunu ifade etmiştir. Böylece hazırladığımız elma suyu karışımları izotonik içecek sınıfında yer almaktadır.

\section{Ortalama kül tayin sonuçları}

Elma suyuna farklı meyvelerin eklenmesinin kül değerleri üzerinde etkili olduğu gözlemlenmiştir. En yüksek kül değerleri sırasıyla ortalama \%0.423 Nar-Elma, \%0.420 Karadut-Elma, \%0.406 KızılcıkElma ve \%0,394 Elma şeklindedir. Kızılcık-Elma içeceğinde kül değerleri istatistiksel olarak önemsiz bulunmuştur. Karadut-Elma ve Nar-Elma sularında artış; Elma suyunda ise azalış gözlemlenmiştir.

RSK; (Richtwerte und Schwankungsbreiten bestimmter Kennzahlen) bir meyve suyunun kimlik ve saflığının saptanmasında faydalanılan özel bileşim unsurlarının düzeyini ifade etmektedir. RSK ortalama değerlerine göre; elma suyunda kül değeri armut suyunda (\%) $0.27 \mathrm{~g}$, (\%) $0.25 \mathrm{~g}$, vişne suyunda (\%) $0.47 \mathrm{~g}$, üzüm suyunda (\%) $0.3 \mathrm{~g}$ olduğu belirtilmektedir (Cemeroğlu ve Karadeniz, 2001). Kökosmanlı ve Keleş (2000) yaptıkları çalışmada kızılıık marmelatlarının kül miktarlarını \%0.30- 0.41 arasında belirlemişlerdir.

\section{Renk değerleri}

Bir gıdanın tüketici üzerinde olumlu bir etki bırakıp bırakmadığının ilk parametresi, ürünün rengidir. Hazırlanan izotonik içeceklerin ortalama $a^{*}($ kırmızı-yeşil), b* (mavi-sarı), L (parlaklık) renk değerleri aşağıdaki çizelgede sırasıyla verilmiştir (Çizelge 3).

Çizelge 3. Hazırlanan izotonik içeceklerin $a^{*}, b^{*}, L^{*}$ değerlerinde depolama süresince görülen değişimler

Table 3. Changes in $a^{*}, b^{*}, L^{*}$ values during storage of prepared isotonic drinks

\begin{tabular}{|c|c|c|c|c|c|}
\hline & Gün & $\begin{array}{c}\text { Elma } \\
\text { Apple-cranberry }\end{array}$ & $\begin{array}{c}\text { Elma-kızılcık } \\
\text { Apple-black mulberry }\end{array}$ & $\begin{array}{c}\text { Elma-karadut } \\
\text { Apple-black mulberry }\end{array}$ & $\begin{array}{c}\text { Elma-nar } \\
\text { Apple-pomegranate }\end{array}$ \\
\hline \multirow{8}{*}{$\stackrel{*}{*}$} & 0 & $3.09 \pm 0.1 \mathrm{~A}^{\mathrm{d}}$ & $1.17 \pm 0.06 \mathrm{C}^{\mathrm{bc}}$ & $1.52 \pm 0.06 \mathrm{~B}^{\mathrm{c}}$ & $1.24 \pm 0.06 C^{a}$ \\
\hline & 15 & $3.18 \pm 0.04 \mathrm{~A}^{\mathrm{d}}$ & $1.04 \pm 0.10 \mathrm{C}^{\mathrm{c}}$ & $1.64 \pm 0.13 \mathrm{~B}^{\mathrm{bc}}$ & $0.98 \pm 0.03 C^{b}$ \\
\hline & 30 & $3.34 \pm 0.06 \mathrm{~A}^{\mathrm{bc}}$ & $1.52 \pm 0.13 \mathrm{C}^{\mathrm{a}}$ & $1.82 \pm 0.11 \mathrm{~B}^{\mathrm{b}}$ & $1.01 \pm 0.18 \mathrm{D}^{\mathrm{b}}$ \\
\hline & 60 & $3.23 \pm 0.06 \mathrm{~A}^{\mathrm{cd}}$ & $1.22 \pm 0.04 C^{b}$ & $2.15 \pm 0.01 \mathrm{~B}^{\mathrm{a}}$ & $0.87 \pm 0.03 D^{b c}$ \\
\hline & 90 & $3.17 \pm 0.05 \mathrm{~A}^{\mathrm{d}}$ & $1.16 \pm 0.01 C^{b c}$ & $1.48 \pm 0.14 \mathrm{~B}^{\mathrm{c}}$ & $0.64 \pm 0.08 D^{c d}$ \\
\hline & 120 & $3.53 \pm 0.06 \mathrm{~A}^{\mathrm{a}}$ & $0.73 \pm 0.10 C^{d}$ & $1.07 \pm 0.07 B^{d}$ & $0.67 \pm 0.13 \mathrm{C}^{\mathrm{cd}}$ \\
\hline & 150 & $2.57 \pm 0.11 \mathrm{~A}^{\mathrm{e}}$ & $1.22 \pm 0.01 \mathrm{~B}^{\mathrm{b}}$ & $0.52 \pm 0.05 C^{e}$ & $0.67 \pm 0.17 \mathrm{C}^{\mathrm{cd}}$ \\
\hline & 180 & $3.41 \pm 0.04 \mathrm{~A}^{\mathrm{ab}}$ & $1.17 \pm 0.08 \mathrm{C}^{\mathrm{bc}}$ & $1.49 \pm 0.15 \mathrm{~B}^{\mathrm{c}}$ & $0.53 \pm 0.16 \mathrm{D}^{\mathrm{d}}$ \\
\hline \multirow{8}{*}{ مـ } & 0 & $3.67 \pm 0,22 \mathrm{~A}^{\mathrm{e}}$ & $1.28 \pm 0.07 B^{d}$ & $1.00 \pm 0.16 \mathrm{C}^{\mathrm{bc}}$ & $0.53 \pm 0.05 \mathrm{D}^{\mathrm{bc}}$ \\
\hline & 15 & $4.93 \pm 0.05 \mathrm{~A}^{\mathrm{a}}$ & $1.53 \pm 0.10 \mathrm{~B}^{\mathrm{c}}$ & $1.05 \pm 0.10 C^{b}$ & $0.60 \pm 0.11 \mathrm{D}^{\mathrm{abc}}$ \\
\hline & 30 & $4.57 \pm 0.12 \mathrm{~A}^{\mathrm{b}}$ & $2.27 \pm 0.16 \mathrm{~B}^{\mathrm{a}}$ & $1.45 \pm 0.11 \mathrm{C}^{\mathrm{a}}$ & $0.86 \pm 0.20 \mathrm{D}^{\mathrm{ab}}$ \\
\hline & 60 & $4.33 \pm 0.11 \mathrm{~A}^{\mathrm{c}}$ & $1.69 \pm 0.08 C^{c}$ & $0.96 \pm 0.08 \mathrm{~B}^{\mathrm{bc}}$ & $0.62 \pm 0.21 \mathrm{D}^{\mathrm{abc}}$ \\
\hline & 90 & $4.05 \pm 0.10 A^{d}$ & $1.99 \pm 0.02 \mathrm{~B}^{\mathrm{b}}$ & $1.20 \pm 0.15 C^{b}$ & $0.36 \pm 0.14 D^{c}$ \\
\hline & 120 & $4.24 \pm 0.09 \mathrm{~A}^{\mathrm{cd}}$ & $0.26 \pm 0.12 C^{f}$ & $0.75 \pm 0.08 \mathrm{~B}^{\mathrm{c}}$ & $0.75 \pm 0.28 \mathrm{~B}^{\mathrm{ab}}$ \\
\hline & 150 & $4.1 \pm 0.18 \mathrm{~A}^{\mathrm{d}}$ & $2.42 \pm 0.21 \mathrm{~B}^{\mathrm{a}}$ & $1.05 \pm 0.13 C^{b}$ & $0.96 \pm 0.27 \mathrm{C}^{\mathrm{a}}$ \\
\hline & 180 & $4.01 \pm 0.01 A^{d}$ & $1.98 \pm 0.15 \mathrm{~B}^{\mathrm{b}}$ & $0.76 \pm 0.21 C^{c}$ & $0.56 \pm 0.19 C^{b c}$ \\
\hline \multirow{8}{*}{$\stackrel{*}{*}$} & 0 & $21.46 \pm 0.02 \mathrm{~B}^{\mathrm{e}}$ & $22.22 \pm 0.02 \mathrm{~A}^{\mathrm{cd}}$ & $20.38 \pm 0.00 C^{c}$ & $19.49 \pm 0.03 D^{e}$ \\
\hline & 15 & $22.38 \pm 0.03 \mathrm{~B}^{\mathrm{a}}$ & $22.57 \pm 0.01 \mathrm{~A}^{\mathrm{b}}$ & $20.46 \pm 006 C^{b c}$ & $20.02 \pm 0.01 D^{b}$ \\
\hline & 30 & $21.62 \pm 0.05 \mathrm{~B}^{\mathrm{d}}$ & $22.05 \pm 0.03 \mathrm{~A}^{\mathrm{d}}$ & $18.82 \pm 0.01 \mathrm{D}^{\mathrm{g}}$ & $19.73 \pm 0.06 \mathrm{C}^{\mathrm{d}}$ \\
\hline & 60 & $21.85 \pm 0.04 A^{c}$ & $20.51 \pm 0.02 B^{f}$ & $20.49 \pm 0.01 \mathrm{~B}^{b}$ & $20.20 \pm 0.06 C^{a}$ \\
\hline & 90 & $21.39 \pm 0.00 B^{f}$ & $22.39 \pm 0.26 A^{c}$ & $19.06 \pm 0.05 D^{f}$ & $19.90 \pm 0.05 C^{c}$ \\
\hline & 120 & $20.92 \pm 0.03 \mathrm{~B}^{\mathrm{g}}$ & $21.18 \pm 0.02 \mathrm{~A}^{\mathrm{e}}$ & $20.63 \pm 0.03 C^{a}$ & $19.29 \pm 0.03 D^{f}$ \\
\hline & 150 & $22.01 \pm 0.01 \mathrm{~B}^{\mathrm{b}}$ & $23.38 \pm 0.08 \mathrm{~A}^{\mathrm{a}}$ & $19.84 \pm 0.08 C^{d}$ & $19.23 \pm 0.00 \mathrm{D}^{\mathrm{f}}$ \\
\hline & 180 & $20.01 \pm 0.05 \mathrm{~B}^{\mathrm{h}}$ & $20.32 \pm 0,05 A^{g}$ & $19.60 \pm 0.04 \mathrm{C}^{\mathrm{e}}$ & $19.55 \pm 0.02 \mathrm{C}^{\mathrm{e}}$ \\
\hline
\end{tabular}

$A, B, C, D:$ Aynı satırda farklı harflerle gösterilen ortalamalar birbirinden farklıdır $(P<0.05)$.

$a, b, c, d, e:$ Aynı sütunda farklı üstel harflerle gösterilen ortalamalar birbirinden farklıdır $(P<0.05)$ 
Fenolik madde grubu içerisinde bulunan antioksidan özelliğe sahip olan $C$ vitamini ve yine antioksidan özelliğe sahip antosiyaninler gibi bazı maddeler düşük sıcaklıklara göre yüksek sıcaklıklardan daha fazla etkilenen maddelerdir (Cemeroglu, 2007). Bundan dolayı antioksidan özelliğe sahip olan bu gibi maddeler yüksek sıcaklıklar ile birlikte parçalanma ile önemli kayıplara maruz kalmaktadırlar. Bu kayıplarla birlikte antioksidan kapasitesinde de önemli azalmalar olabilmektedir.

Karadutun antioksidan kapasitesinin belirlenmesi amacıyla farklı yöntemler kullanılarak çeşitli çalışmalar yapılmış, bu çalışmalarda karadutun orta seviyelerde antioksidan aktivite (6.8-14.4 $\mu \mathrm{g} \quad \mathrm{TE} / \mathrm{gr}$ ) gösterdiği saptanmıştır (Hassımotto, 2005). Dut pekmezinin depolanması ile ilgili yapılan bir çalışmada $20 \pm 2{ }^{\circ} \mathrm{C}^{\prime}$ de depolanan pekmezlerde antioksidan aktivitesinde azalma olduğu belirtilmiştir (Zor, 2007). Tezcan ve arkadaşları (2009) inceledikleri yedi faklı ticari nar suyunun antioksidan değerlerini 25.19 \pm 0.47 $67.46 \pm 2.54$ arasında belirlemişlerdir.

Antioksidan aktivitenin depolamanın etkisi dışında da çeşitli proses aşamalarında değişiklik meydana geldiğini gösteren araştırmalara rastlanmıştır. Yang ve ark. (2007), Pasifik
Adaları'nda yaşayan halk tarafından ilaç amaçlı kullanılan tropik bir meyve olan noni'den elde edilen meyve suyundan antioksidan aktivitenin üretimin çeşitli basamaklarında değiştiğini ortaya koymuştur. Örneğin; $24^{\circ} \mathrm{C}^{\prime}$ de üç ay süre boyunca fermente edilmiş noni sularında, antioksidan aktivitelerinin seviyesinde \%90 üzerinde bir kayıp belirlenmiştir. Aynı noni sularının $24^{\circ} \mathrm{C}, 4^{\circ} \mathrm{C}$ ve $18^{\circ} \mathrm{C}$ sıcaklıklarında üç ay boyunca depolanması sonucunda, antioksidan aktivite seviyelerinde sırasıyla \%90, \%55 ve \%15 azalma belirlenmiştir. Sonuç olarak nonide elde edilen meyve sularında depolama sıcaklığı arttıkça buna bağlı antioksidan aktivitenin düştüğü saptanmıştır.

\section{Toplam fenolik madde miktarı değerleri}

Hazırlanan içeceklerin ilk aylarda fenolik madde miktarı değerleri yüksek olup zamanla bu değerlerde bir azalma görülmüştür. Depolama boyunca oluşan değişiklikler istatistiksel açıdan önemli bulunmuştur $(P<0.05)$. En yüksek fenolik madde değeri sırasıyla Nar-Elma, Kızılcık-Elma, Karadut-Elma ve Elma şeklindedir (Çizelge 5).

Çizelge 5. İzotonik içeceklerin toplam fenolik madde miktarları değerlerinde depolama süresince görülen değişimler (mg gallik asit/g)

Table 5. Changes in amount of total phenolic matter values during storage of isotonic drinks (mg gallik asit/g)

\begin{tabular}{|c|c|c|c|c|}
\hline Günler & $\begin{array}{c}\text { Elma } \\
\text { Apple }\end{array}$ & $\begin{array}{c}\text { Elma-kızılcık } \\
\text { Apple-cranberry }\end{array}$ & $\begin{array}{c}\text { Elma-karadut } \\
\text { Apple-black mulberry }\end{array}$ & $\begin{array}{c}\text { Elma-nar } \\
\text { Apple-pomegranate }\end{array}$ \\
\hline 0 & $31.34 \pm 0.01 \mathrm{C}^{\mathrm{ab}}$ & $59.20 \pm 0.01 \mathrm{~B}^{\mathrm{a}}$ & $38.81 \pm 0.02 \mathrm{C}^{\mathrm{bc}}$ & $76.54 \pm 0.11 \mathrm{~A}^{\mathrm{c}}$ \\
\hline 15 & $35.84 \pm 0.00 \mathrm{D}^{\mathrm{a}}$ & $65.49 \pm 0.00 \mathrm{~B}^{\mathrm{a}}$ & $49.69 \pm 0.10 \mathrm{C}^{\mathrm{a}}$ & $91.61 \pm 0.00 \mathrm{~A}^{\mathrm{ab}}$ \\
\hline 30 & $35.60 \pm 0.00 \mathrm{D}^{\mathrm{a}}$ & $68.15 \pm 0.00 \mathrm{~B}^{\mathrm{a}}$ & $49.96 \pm 0.00 \mathrm{C}^{\mathrm{a}}$ & $101.10 \pm 0.03 \mathrm{~A}^{\mathrm{a}}$ \\
\hline 60 & $32.78 \pm 0.00 \mathrm{D}^{\mathrm{ab}}$ & $60.81 \pm 0.1 \mathrm{~B}^{\mathrm{a}}$ & $48.12 \pm 0.00 \mathrm{C}^{\mathrm{a}}$ & $86.91 \pm 0.00 \mathrm{~A}^{\mathrm{bc}}$ \\
\hline 90 & $35.65 \pm 0.00 \mathrm{D}^{\mathrm{a}}$ & $69.60 \pm 0.00 \mathrm{~B}^{\mathrm{a}}$ & $48.50 \pm 0.01 \mathrm{C}^{\mathrm{a}}$ & $80.97 \pm 0.00 \mathrm{~A}^{\mathrm{bc}}$ \\
\hline 120 & $30.59 \pm 0.00 \mathrm{C}^{\mathrm{b}}$ & $64.79 \pm 0.01 \mathrm{~B}^{\mathrm{a}}$ & $45.42 \pm 0.00 \mathrm{C}^{\mathrm{ab}}$ & $90.18 \pm 0.01 \mathrm{~A}^{\mathrm{abc}}$ \\
\hline 150 & $32.29 \pm 0.00 \mathrm{~B}^{\mathrm{ab}}$ & $66.57 \pm 0.00 \mathrm{~A}^{\mathrm{a}}$ & $35.81 \pm 0.00 \mathrm{~B}^{\mathrm{c}}$ & $63.72 \pm 0.00 \mathrm{~A}^{\mathrm{d}}$ \\
\hline 180 & $29.2 \pm 0.00 \mathrm{C}^{\mathrm{b}}$ & $35.66 \pm 0.00 \mathrm{~B}^{\mathrm{b}}$ & $25.25 \pm 0.02 \mathrm{C}^{\mathrm{d}}$ & $50.49 \pm 0.00 \mathrm{~A}^{\mathrm{e}}$ \\
\hline
\end{tabular}

$A, B, C, D:$ Aynı satırda farklı harflerle gösterilen ortalamalar birbirinden farklıdır $(P<0.05)$.

a,b,c,d,e: Aynı sütunda farklı üstel harflerle gösterilen ortalamalar birbirinden farklıdır $(P<0.05)$.

Ercisli ve Orhan (2007) karadut, kırmızı ve beyaz dutun kimyasal kompozisyonlarını incelediklerinde en yüksek fenolik madde miktarını karadutta ve 1422 mg GAE/100g olarak belirlemişlerdir. Kafkas ve ark. (2006) karadutun toplam fenolik madde içeriğini $340.6 \mathrm{mg} / 100 \mathrm{~g}$ gallik asit olarak bulmuşlardır. Özgen ve ark. (2009), karadutta ve kırmızı dutta toplam fenolik madde değerlerini sırasıyla $27.37 \mathrm{mg} \mathrm{GAE} / \mathrm{g}$ ve $16.03 \mathrm{mg} \mathrm{GAE} / \mathrm{g}$ olarak belirlemişlerdir. Bu durum karadutun kırmızı duta göre fenolik maddelerce daha zengin bir meyve olduğunu göstermektedir.

Tezcan ve arkadaşları (2009) yapmış oldukları çalışmada bazı ticari nar sularının toplam fenolik madde miktarlarını incelemişlerdir. Elde edilen sonuçlar 144-10086 mg GAE/ L olarak 
belirlemişlerdir. Muhacir-Güzel ve arkadaşları (2014) çalışmalarında tüm meyveden ve keseciklerden elde edilen nar sularının bazı proses aşamalarında incelemelerde bulunmuşlar ve toplam fenolik madde içeriğini 1590-3023 mg $\mathrm{GAE} / \mathrm{L}$ olarak tespit etmişlerdir.

\section{Duyusal özellikler}

Bir gıda maddesinin tüketici tarafından ilk albenisini görünüş koku ve tat oluşturmaktadır.
$\mathrm{Bu}$ yüzden duyusal özellikler tüketme ve satın alma kararını etkileyen en önemli kalite kriterlerinden biridir. Duyusal değerlendirme formuna göre panelistlerden içecek gruplarını görünüş, koku ve tat olarak değerlendirmeleri istenmiştir. Aynı zamanda örneklerin renk, ağızda bıraktığı his ve sonradan hissedilen tat ile ilgili değerlendirmelerini skalada (1-5 arası) belirtmeleri istenmiştir.

Çizelge 6. İzotonik içeceklerin özelliği ve içeceklerin ortalama tahmini değerleri

Table 6. Feature of isotonic drinks and mean estimated values of drinks

\begin{tabular}{|c|c|c|c|c|}
\hline & \multirow{2}{*}{$\begin{array}{l}\text { Ortalama } \\
\text { Mean }\end{array}$} & \multirow{2}{*}{$\begin{array}{c}\text { Std hata } \\
\text { Std. } \\
\text { error }\end{array}$} & \multicolumn{2}{|c|}{$\begin{array}{l}\text { 95\% Güven aralığı } \\
\text { Confidence interval }\end{array}$} \\
\hline & & & $\begin{array}{c}\text { Alt değer } \\
\text { Lower bound }\end{array}$ & $\begin{array}{c}\text { Üst değer } \\
\text { Upper bound }\end{array}$ \\
\hline \multicolumn{5}{|l|}{ Bileşim } \\
\hline \multicolumn{5}{|l|}{ Composition } \\
\hline Elma & 4.50 & 0.14 & 4.18 & 4.82 \\
\hline Kızılcık-Elma & 3.83 & 0.16 & 3.47 & 4.19 \\
\hline Karadut-Elma & 3.13 & 0.30 & 2.45 & 3.82 \\
\hline Nar-Elma & 3.43 & 0.35 & 2.64 & 4.23 \\
\hline \multicolumn{5}{|l|}{ Duyusal Özellikler } \\
\hline \multicolumn{5}{|l|}{ Feature of composition } \\
\hline Renk & 4.20 & 0.18 & 3.80 & 4.60 \\
\hline Ağızda bıraktğı his & 3.55 & 0.22 & 3.05 & 4.05 \\
\hline Sonradan hissedilen (gecikmiş) tat & 3.43 & 0.26 & 2.85 & 4.00 \\
\hline
\end{tabular}

Çizelge 6'dan görülebileceği gibi, izotonik içecekler için ortalama değerlere göre sıralama yapıldığında, en yüksek ortalama değeri elma, ardından kızılcık-elma, müteakiben nar-elma ve karadut-elma örnekleri vermiştir.

Genel izlenim açısından izotonik içeceklerden en çok elma içeceği, en az ise nar-elma içeceği beğenilmiştir. Nar-elma içeceğin de sonradan hissedilen tadın diğer gruplara göre hoşa gitmediği ve buruk bir tada sahip olduğu ifade edilmiştir. Duyusal değerlendirme sonuçlarına göre genel olarak; elma, kızılcık-elma ve nar-elma içeceklerinin görünüşleri berrak olarak değerlendirilmiştir. Karadut-elma içeceğinde yabancı bir koku hissedilmiş olup, diğer grupların kendine has bir kokuya sahip olduğu ifade edilmiştir. Elma ve karadut-elma tatlı bulunurken, kızılcık-elma ve nar-elma içeceklerinde ekşi bir tat hissedildiği belirtilmiştir.

\section{Sonuçlar}

Bu çalışma ile Türkiye'de meyve suyu üretiminde birinci sırada olan elma sularının içecek endüstrisinde farklı kullanım olanakları araştırılmış olup, endüstriye yeni bir ürünün kazandırılması amaçlanmıştır. Hazırlanan izotonik içeceklerin depolanmaları boyunca fiziksel, kimyasal ve duyusal analizlerde ortaya çıkan değişimler araştırılmıştır.

Depolama boyunca, $\mathrm{pH}$, renk, ve titrasyon asitliğinde meydana gelen değişimler önemli bulunmuştur. SÇKM, toplam kuru madde ve kül değerlerindeki değişimlerin önemli olmadığı belirlenmiştir. Elma suyuna diğer meyve sularının özellikle nar ve kızılcık sularının eklenmesiyle fenolik ve antioksidan aktivite bakımından önemli derecede artış olduğu görülmüştür. İzotonik içeceklerin toplam fenolik madde içeriği ile antioksidan kapasitesi arasında doğrusal ve pozitif korelasyonun olduğu görülmüştür. Yapılan TFMM 
analizinde depolama boyunca Nar-Elma ve Kızılcık-Elma sularında diğer gruplardan daha yüksek sonuçlar elde edilmiştir. Bunu KaradutElma, Elma takip etmektedir. Depolama boyunca dört grupta meydana gelen farklılıklar istatistiksel olarak önemli olduğu tespit edilmiştir. Antioksidan kapasitenin, kırmızı renk yoğunluğu $\left(a^{*}\right)$ ile doğrusal bir ilişkisi olduğu görülmüştür. Bu doğrultuda koyu renkli meyve sularının daha yüksek seviyede antioksidan içerdiği tespit edilmiştir. Sonuçlar, kırmızı meyvelerin antioksidan kapasitesi ve TFM içeriğine katkısını açıkça göstermektedir. Kırmızı meyvelerle zenginleştirilmiş elma suyunun, sağlık üzerinde besleyici bir işlevi olan yeni içeceklerin tasarımında potansiyel olarak ilgi çekici olabileceğini göstermiştir. İzotonik içecekler, görünüş, tat, koku ve genel kabul edilebilirlik gibi özellikler bakımından değerlendirildiklerinde elma suyunun panelistler tarafından çoğunlukla daha çok beğenildiği anlaşılmıştır.

Diğer meyve suları ile zenginleştirilmiş izotonik elma sularının tüketiciler tarafından tercih edilebileceği, özellikle antreman esnasında susuzluğu gidermek, kaybolan elektrolitleri geri kazanmak ve açlık hissini engellemek için kullanılabileceği, yapısında fenolik ve antioksidan maddelerce zengin olduğu; doğal bir ürün olan böyle bir içeceğin gıda sanayisinde rahatlıkla kullanılabileceği tahmin edilmektedir. İzotonik içecekler konusundaki çalışmaların arttırılması gıda endüstrisine yeni içecekler kazandırılması yanında hem sporcuların tüketimi için iyi bir alternatif hem de özellikle halk sağlığı için yararlı içeceklerin üretimi açısından faydalı olacaktır.

\section{Ekler}

Bu Makale, Öznur TOĞRUL'un Harran Üniversitesi Fen Bilimleri Enstitüsüne sunmuş olduğu Yüksek Lisans Tezinden yararlanılarak hazırlanmış olup Harran Üniversitesi Bilimsel Araştırma Projeleri Koordinasyon Birimince 15051 nolu proje ile desteklenmiştir.

\section{Çıkar Çatışması Beyanı: Makale yazarları}

aralarında herhangi bir çıkar çatışması olmadığını beyan ederler.

\section{Kaynaklar}

Akbulut, M., Çekiç, Ç., \& Çoklar, H. (2006). Farklı Dut Çeşitlerinin Bazı Kimyasal Özellikleri ve Mineral Madde İçeriklerinin Belirlenmesi, Gıda Teknolojisi (s. 20-24). Ankara: Detay Yayıncilık.

Altuğ, T., \& Elmacı, Y. (2011). Gıdalarda Duyusal Değerlendirme (s. 134). ìzmir: Sidas Yayınları.

Anonymous, (2012). Meyve Suyu Sektör İstatistikleri. Erişim adresi: http://www.meyed.org.tr.

Bounous, G., \& Zanini, E. (1987). The Variability of Some Components and Biometric Characteristics of the Fruits of Six Tree and Shrub Species. In Lampone, Mirtillo ed Altri Piccoli Frutti, atti, Convegno, Trente, 4-5 Giugni 1987, Rome-Italy, 189197.

Cemeroğlu, B., \& Karadeniz F. (2001). Meyve Suyu Üretim Teknolojisi (s. 384). Ankara: Gıda Teknolojisi Yayınları.

Cemeroglu, B. (2007). Gıda Analizleri (s. 34). Ankara: Gıda Teknolojisi Yayınları.

Curran, P. J., West, S. G., \& Finch, J. F. (1996). The Robustness of Test Statistics to Nonnormality and Specification Error in Confirmatory Factor Analysis. Psychol Methods, 1(1), 16-29.

Demir, F., \& Kalyoncu, i.H. (2003). Some Nutritional, Pomological and Physical Properties of Cornelian Cherry (Cornus mas L.). Journal of Food Engineering, 60(3), 335-341.

Elmacl, Y., \& Altuğ, T. (2002). Flavour Evaluation of Three Black Mulberry (Morus nigra) Cultivars Using Gc/Ms, Chemical and Sensory Data. Journal of The Science of Food and Agriculture, 82(6), 632-635.

Ercişli, S., \& Orhan, E. (2007). Chemical Composition of White (Morus Alba), Red (Morus Rubra) and Black (Morus nigra) Mulberry Fruits. Food Chemistry, 103(4), 1380-1384.

Ercişli, S., (2004). Cornelian Cherry Germplasm Resources of Turkey. Journal of Fruit and Ornamental Plant Research Special Ed., 12, 87-92.

Ersoy, N., \& Ersoy, G., (2013). Hidrasyon için spor içecekleri ve alternatif içecekler. Türkiye Klinikleri Spor Bilimleri Dergisi, 5(2), 96-100.

Espín, J.C., Soler-Rivas, C., Wichers, H.J., \& Garcia-Viguera, C. (2000). Anthocyanin-Based Natural Colorants: A New Source of Antiradical Activity for Foodstuff. J. Agric. Food Chemistry, 48(5), 1588-1592.

Fadavı, A., Barzegar, M., Azızı, M. H., \& Bayat, M., (2005). Physicochemical Composition of Ten Pomegranate Cultivars (Punica granatum L.) Grown in Iran. Food Science and Technology International, 11(2), 113119.

Gironés-Vilaplana, A., Valentão, P., Moreno, D.A., Ferreres, F., García-Viguera, C., \& Andrade, P.B. (2012). New Beverages of Lemon Juice Enriched With The Exotic Berries Maqui, Açaí, and Blackthorn: Bioactive Components and in Vitro Biological Properties. Journal of Agricultural and Food Chemistry, 60(26), 6571-6580. 
Gould, A.W., (1977). Food Quality Assurance. The AVI Publ. Co. Inc. USA.314s.

Hepsağ, F., Hayoğlu, i. \& Hepsağ B. (2012). Karadut Meyvesinin Antosiyanin İçeriği ve Antosiyaninlerin Gıda Sanayinde Renk Maddesi Olarak Kullanım Olanakları. Gıda Teknolojileri Elektonik Dergisi, 7(1), 9-19.

Hassımotto N.M., Genovese M.I., \& Lajolo F.M. (2005). Antioxidant Activity of Fruits, Vegetables, and Commercial Frozen Fruit Pulps. J. Agric. Food Chem, 53(8), 2928-2935.

Kafkas, E., Bozdoğan, A., Burgut, A., Türemiş, N., Kargı, S.P., \& Cabaroğlu, T. (2006). Bazı Üzümsü Meyvelerde Toplam Fenol ve Antosiyanin İçerikleri. II.Ulusal Üzümsü Meyveler Sempozyumu, (s. 309-312). Tokat

Karaman, Ş., Tutem, E., Baskan, S.K., \& Apak, R. (2010). Comparison of Total Antioxidant Capacity and Phenolic Composition of Some Apple Juices with Combined HPLC-CUPRAC Assay. Food Chemistry, 120 (4), 1201-1209.

Kökosmanlı, M., \& Keleş, F., (2000). Erzurum'da Yetiştirilen Kızılcık Meyvesinin Marmelat ve Pulpa İşlenerek Değerlendirilmesi. Gıda, 25 (4), 289- 298.

Kulkarni, A.P., \& Aradhya, S.M. (2005). Chemical Changes and Antioxidant Activity Pomegranate Arils During Fruit Development. Food Chemistry, 93, 319-324.

Mackenzıe, B. (2000) Spor içcecekleri. Retrieved from: https://www.brianmac.co.uk/drinks.htm.

Medina-Remon A., Barrionuevo-González A., Zamora-Ros R., Andres-Lacueva C. Estruchb R., Martínez-Gonzálezc MA.,Diez-Espino J., \& Lamuela-Raventos RM., (2009). Rapid Folin-Ciocalteu Method Using Microtiter 96well Plate Catridges for Solid Phase Extraction to Assess Urinary Total PhenolicCompounds, as a Biomarker of Total Polyphenols İntake. Analytica Chimica Acta, 634, 54-60.

Muhacir-Güzel N., Türkyılmaz M., Yemiş O., Taği S., \& Özkan M. (2014). Changes in Hydrolysable and Condensed Tannins of Pomegranate (Punica Granatum L., Cv. Hicaznar) Juices From Sacs and Whole Fruits During Production and Their Relation with Antioxidant Activity. Lwt -FoodScience and Technology, 59(2), 933-940.

Oliveira B.G., Filho E.B.A., Ventura E., Do Monte S.A., Junior C.G.L., Rocha G.B., \& Vasconcellos M.L.A.A. (2007). Synthesis and Conformational Study af a New Class of Highly Bioactive Compounds. Chemical Physics Letters, 449(4), 336-340.
Özden, N.A., Ak, B. A., \& Özden, M. (2017). Farklı Nar (Punica granatum L.) Çeşitlerinin Pomolojik, Fitokimyasal Özellikleri ve Antioksidan Kapasiteleri. Harran Tarım ve Gıda Bilimleri Dergisi. 21(2): 164176.

Özgen, M., \& Tokbaş, H. (2007). Işılklanma ve Meyve Dokusunun Amasya ve Fuji Elmalarında Antioksidan Kapasitesine Etkisi. Gazi Osmanpaşa Üniversitesi Ziraat Fakültesi Dergisi, 24(2), 1-5.

Özgen, M., Serçe, S., \& Kaya, C. (2009). Phytochemical and Antioxidant Properties of Anthocyanin-Rich Morus Nigra and Morus Rubra Fruits. Scientia Horticulturae, 119(3), 275-279.

Özgen, M., Günes, M., Akça, Y., Türemis, N., Ilgın, M., Kızılcı, G., Erdogan, Ü., \& Serçe S. (2009b). Morphological Characterization Several Morus Sp. From Turkey. Horticulture Environment and Biotechnology, 50 (1), 9- 15.

Rehrer, N.J. (1994). The Maintenance of Fluid Balance During Exercise. International Journal of Sports Medicine,15(3), 122-125.

Tezcan, F., Gultekın-Ozguven, M., Dıken, T., Ozcelık, B., \& Erım, F. B. (2009). Antioxidant Activity and Total Phenolic, Organic Acid and Sugar Content in Commercial Pomegranate Juices. Food Chemistry, 115, 873-877.

Tüfekçi, H. (2008). Piyasada Satılan Bazı Meyve Sularının Özelliklerinin Gıda Mevzuatına Uygunluğunun Araştırılması. Yüksek Lisans Tezi, Çukurova Üniversitesi, Adana.

Yang, J., Paulina, R., Janke-Stedronsky, S., \& Abawi, F. (2007). Free-Radical scavenging Activity and Total Phenols of Noni (Morinda citrifolia L.) Juice and Powder in Processing and Storage. Food Chemistry, 102, 302-308.

Yıldırım, A., Toğrul, Ö., Çetin, S., Öğretmen, H. Sarı, P., \& Hayoğlu, i. (2016). Narın Çikolata Üretiminde Kullanımı. Harran Tarım ve Gıda Bilimleri Dergisi. 20 (1): 12-19.

Zaouaya,F., Menab, P., Garcia-Viguerab, C., \& Marsa M. (2012). Antioxidant Activity and Physico Chemical Properties of Tunisian grown pomegranate (Punica granatum L.) cultivars. Industrial Crops and Products, 40, 81- 89.

Zor, M., (2007). Depolamanın Ayva Reçelinin Bazı Fiziksel ve Kimyasal Özellikleri ile Antioksidan Aktivitesi Üzerine Etkisi. Yüksek Lisans Tezi, Atatürk Üniversitesi, Erzurum. 